$\begin{array}{lll}\text { KULTURA } & \begin{array}{l}\text { POLSKA AKADEMIANAUK } \\ \text { KOMITET SOCJOLOGII }\end{array} & \text { ISSN 0023-5172 } \\ \text { i } & \begin{array}{l}\text { INSTYTUT STUDIÓW POLITYCZNYCH } \\ \text { SPOLECLENSTWO }\end{array} & \\ 2009, \text { nr } 2 \quad \text { MIASTO } & \end{array}$

TOMASZ NAWROCKI

Uniwersytet Ślaski w Katowicach

\title{
PRZYCZYNEK DO RECEPCJI ŚLĄSKIEJ MONOGRAFII JÓZEFA CHAŁASIŃSKIEGO*
}

Współczesne losy prac ważnych dla rozwoju polskiej socjologii nie zawsze są podobne. Niektóre $z$ nich są stale obecne, stają się przedmiotem kolejnych studiów, inspirują kontynuatorów. Inne pojawiają się tylko w niewielkich wzmiankach lub w przypisach, kiedy należy wykazać się znajomością dokonań naszych poprzedników i oddać im należną cześć. Dotyczy to niekiedy dzieł tego samego autora. Tak jest właśnie w przypadku dokonań Józefa Chałasińskiego. $\mathrm{Z}$ jednej strony ciągle obecne $\mathrm{w}$ polskiej socjologii studia poświęcone kulturze narodowej lub polskiemu chłopstwu ${ }^{1}$. Z drugiej ceniona, choć już trochę zapomniana monografia z 1935 r.: Antagonizm polsko-niemiecki w osadzie fabrycznej „Kopalnia” na Górnym Śląsk². Praca, która leży u podstaw rozwoju nowoczesnych socjologicznych badań monograficznych w Polsce. Jej wpływ na rozwój metody badawczej, która przez lata była wizytówką polskiej socjologii empirycznej3 ${ }^{3}$, jest trudny do przecenienia. Nie wznawiane od tego czasu studium Chałasińskiego nie tylko rozpoczęło długą polską tradycję badań społecznych tego regionu (opracowanie konkursu PIS na życiorysy Ślą-

Adres do korespondencji: Instytut Socjologii Uniwersytetu Śląskiego, ul. Bankowa 11, 40-007 Katowice; tomasz.nawrocki@us.edu.pl

${ }^{*}$ Tekst powstał podczas zbierania materiału do książki: T. Nawrocki, Trwanie $i$ zmiana lokalnej społeczności górniczej na Górnym Ślasku, Katowice 2006.

1 Najnowszym dowodem na to mogą być np. teksty z jubileuszowego numeru „Kultury i Społeczeństwa” 2006, nr 3: B. Borawska, Józef Chałasiński. O aktualności Jego myśli i jej przydatności do wspótczesnych badań nad awansem edukacyjnym; M. Jaworowska, Europa, europejskość i naród w twórczości Józefa Chałasińnkiego; albo tom pokonferencyjny: Józef Chałasiński (1904-1979) w 100-lecie urodzin i 25-lecie śmierci, B. Gołębiowski (red.), Katowice 2006.

2 J. Chałasiński, Antagonizm polsko-niemiecki w osadzie fabrycznej „Kopalnia” na Górnym Ślasku. Studium socjologiczne, „Przegląd Socjologiczny” 1935, t. 3.

3 W. Kwaśniewicz, Badania monograficzne, „Kultura i Społeczeństwo” 19 , nr 3. 
zaków przerwała wojna) ${ }^{4}$, ale też wraz z badaniami Krystyny Dudy-Dziewierz ${ }^{5}$ i Kazimierza Dobrowolskiego ${ }^{6}$ określiło rozwój polskich badań monograficznych. Dlatego warto po przeszło siedemdziesięciu latach przyjrzeć się temu, jak Antagonizm polsko-niemiecki był odbierany zaraz po jego opublikowaniu i zadać sobie pytanie, co z dzieła Chałasińskiego przetrwało próbę czasu?

\section{MONOGRAFIA ŚLĄSKIEJ OSADY PIÓRA JÓZEFA CHAŁASIŃSKIEGO}

Co skłoniło Chałasińskiego do podjęcia badań w podkatowickich Murckach? $\mathrm{W}$ jego zamierzeniu monografia osady miała nie tylko stanowić przyczynek do „socjologicznego zagadnienia antagonizmów grupowych”, ale też „zwrócić uwagę na potrzebę socjologicznych badań pewnego typu w Polsce" 7 . Pod wpływem kontaktu $z$ dokonaniami amerykańskiej socjologii (klasyczna monografia Middletown Lyndów ${ }^{8}$ ) i polskich badań swego nauczyciela Floriana Znanieckiego (monografia Poznania ${ }^{9}$ ) autor Antagonizmu polsko-niemieckiego upominał się o rozwój badań monograficznych w rodzimej socjologii. Ze względu na "rozpiętość różnic społecznych i kulturalnych, różnorodność problemów” oraz tempo zmian ówczesne społeczeństwo polskie stanowiło prawdziwe laboratorium, „o jakie trudno gdzie indziej”. Dlatego postulował powstawanie „socjologicznych monografij miejscowości (czy całych dzielnic), pojętych jako żywe zbiorowości ludzkie" 10 . Wypełniłyby one istniejącą, jego zdaniem, lukę, gdyż — jak pisał — „mamy w polskim języku szereg cennych historycznych i społeczno-gospodarczych monografij miejscowości, nie mamy jednak w ogóle, ani jednej socjologicznej monografii miejscowości" ${ }^{11}$.

Według Chałasińskiego, monografia taka w odróżnieniu od pozostałych typów monografii ,jest opisem procesów życia zbiorowego miejscowości jako grupy społecznej i ześrodkowuje się na żywych ludziach, a nie na wytworach. Wytwory społeczne uwzględnia ona $\mathrm{w}$ związku $\mathrm{z}$ postawami i dążeniami społecznemi ludzi, oraz w związku z problemami, konfliktami i antagonizmami, rozwijającymi się na tle tych postaw i dążeń. Pełna monografja socjologiczna miejscowości jako grupy społecznej, nie może się więc nigdy ograniczyć do opisu samych wytworów. Musi ona uwzględniać zarówno strukturę społeczną

4 W. Mrozek, Tradycja badań socjologicznych na Górnym Ślasku, w: Społeczne problemy Górnego Ślaska we wspótczesnych badaniach socjologicznych, W. Świątkiewicz (red.), Katowice 1994.

${ }^{5} \mathrm{~K}$. Duda-Dziewierz, Wieś małopolska a emigracja amerykańska. Studium wsi Babica powiatu rzeszowskiego, Polski Instytut Socjologiczny, Warszawa-Poznań 1938.

${ }^{6}$ K. Dobrowolski, Dzieje wsi Niedźwiada, w: Studia z historii społecznej i gospodarczej, Lwów 1931.

${ }^{7}$ J. Chałasiński, Antagonizm polsko-niemiecki, cyt. wyd., s. 5.

8 R. S. Lynd, H. M. Lynd, Middletown: A Study in Contemporary American Culture, Harcourt, Brace and Company, New York 1929.

9 F. Znaniecki, J. Ziółkowski, Czym jest dla ciebie miasto Poznań? Dwa konkursy, PWN, Warszawa Poznań 1984.

10 J. Chałasiński, Antagonizm polsko-niemiecki, cyt. wyd., s. 7.

11 Tamże, s. 6. 
miejscowości, jak i jej dynamikę, czy kompleksy społecznych postaw i dążeń: indywidualnych i zbiorowych, które sprawiają, że miejscowość żyje i rozwija się" 12 .

Tak rozumiane badania monograficzne uzupełniają się z socjologią ogólną i systematyczną. Zawdzięczają socjologii ogólnej „zasadnicze drogowskazy, bez których badacz zgubiłby się w rzeczywistości społecznej”. Jednocześnie badania monograficzne „dostarczają materiału empirycznego dla uogólnień; pozwalają sprawdzać ogólne hipotezy; wskazują często nowe drogi i nowe problemy dla dociekań i w ten sposób chronią badacza przed jałową spekulacją filozoficzną" 13 .

Postulowane przez Chałasińskiego badania monograficzne przyczyniłyby się w ten sposób do rozwoju socjologii teoretycznej. Miały jednak dla niego też ogromne znaczenie praktyczne w walce $z$, ignorancją wykształconych kół społeczeństwa". Uważał bowiem, że ówczesna znajomość polskiej rzeczywistości społecznej „była znikoma”. Wierzył, że to właśnie dzięki studiom monograficznym lepiej można byłoby dotrzeć do „głębszej, wewnętrznej strony polskiego społeczeństwa” i zrozumieć je „w całem jego ogromnym zróżnicowaniu” ${ }^{14}$. Nabierało to szczególnego znaczenia w przypadku polskiej części Górnego Śląska, która była wówczas dla polskiego społeczeństwa ziemią nieznaną.

Chałasiński uważał, że by tak się mogło stać, monografie powinny podejmować najbardziej „żywotne problemy” danej miejscowości, „które nurtują jej życie zbiorowe i są przedmiotem zbiorowych dążeń i konfliktów" ${ }^{15}$. W ten sposób opowiadał się nie za szczegółowym opisem całej społeczności lokalnej, ale za skoncentrowaniem się na jednym aspekcie jej społecznego życia. Problemie najważniejszym dla badacza i dla mieszkańców miejscowości.

Tym najbardziej żywotnym problemem badanej miejscowości był, według autora, antagonizm między polskimi i niemieckimi mieszkańcami osady ${ }^{16}$. Przenikać on miał wszystkie sfery życia Murcek, wpływał na zachodzące tam stosunki społeczne. Dlatego monografia miała pokazać lokalne uwarunkowania antagonizmu oraz znaczenie polsko-niemieckich konfliktów dla życia społeczności osady.

Przyczyn antagonizmu Chałasiński doszukiwał się głęboko w przeszłości Murcek. Według niego, na charakter współczesnych mu relacji między Polakami i Niemcami miały wpływ z jednej strony działania władz niemieckich wobec Polaków (sięgnął na przykład do okresu Kulturkampfu), z drugiej zaś tradycja lokalnych konfliktów między zarządem dóbr magnata a ludnością polską. Pozornie proste konflikty „narastały z pokolenia na pokolenie”. Nakładały

\footnotetext{
12 Tamże.

13 Tamże.

14 Tamże, s. 7.

15 Tamże, s. 8.

16 Tamże, s. 25.
} 
się na siebie antagonizmy osobiste i grupowe. „Tam bowiem gdzie istnieje tradycja antagonizmu zbiorowego, bardzo łatwo zatraca się poczucie granicy kolizyj osobistych i kolizyj grupowych. Urazy osobiste i chęć odwetu pogłębiają antagonizm grupowy" ${ }^{17}$. Uchwycenie tego procesu w analizie to jedna z największych zalet pracy.

$\mathrm{Na}$ lokalny charakter antagonizmu polsko-niemieckiego nakładają się konflikty socjalne. Dla Chałasińskiego Polacy w osadzie byli „masą robotniczą, tubylcami wydziedziczonymi przez Niemców”. Niemcy to „Herrenvolk, przybysze, obcy”. Dwa „odrębne i obce sobie światy”. Tak jak w gospodzie, w której „polski plebs, miał salę na dole, a niemiecki Herrenvolk, urzędnicy kopalni, na górze, dokąd pospólstwo miało wejście wzbronione. Cały system społeczny osady opierał się na takiej izolacji dwóch warstw ludności" ${ }^{18}$. W tej sytuacji antagonizm narodowy był nierozłącznie powiązany $z$ antagonizmem socjalnym. Jeden warunkował drugi, wzmacniając poczucie niechęci między grupami.

Tak rozumiany antagonizm miał miejsce w społeczności pogranicza. Pojęciem tym Chałasiński posługiwał się w celu określenia społeczności, w której „role społeczne mieszanej ludności są nieustalone”, gdzie nie wiadomo było, kto jest Polakiem, a kto Niemcem, gdzie zanikają „wszelkie rzeczowe i objektywne podstawy do przeprowadzenia granicy pomiędzy swoimi i obcymi". Na pograniczu wątpliwości mogą dotyczyć „najgłębszych wiązań własnego ja”, więc określenia, kim jestem, gdzie "kończą się "swoi», a zaczynają "obcy»" 19 . Niemożność takiego tradycyjnego rozgraniczenia ról społecznych uniemożliwia wytworzenie się poczucia odrębności grup i jednostek. „Zachwianie tych rozgraniczeń podważa porządek społeczny, któremu jednostki i grupy zawdzięczają swoje poczucie znaczenia. Dlatego zagrożenie systemu ról społecznych, $z$ którym nasze «ja» i poczucie wartości jest nierozłącznie związane, powoduje obronną reakcję antagonistyczną" 20 . W ten sposób Chałasiński dowodzi, że antagonizm międzygrupowy staje się cechą immanentną społeczności pogranicza.

Dodaje też dalej, że na pograniczu rozgrywa się konflikt „ekspansywnych dążeń narodów i państw”. Wymaga się tutaj „aktywnego i ekspansywnego poczucia narodowego". Ekspansja narodowa jest tu „obowiązkiem każdego" ${ }^{21}$. Każdy mieszkaniec pogranicza musi opowiedzieć się „za jedną lub za drugą grupą. Przyczem zadeklarowanie swojej przynależności musi być bezwzględne i całkowite; w żadnej ważnej sferze życia nie wolno być jednostce narodowo-nieokreślonym" 22.

Kategorie te zostały wykorzystane do analizy antagonizmu polsko-niemieckiego w osadzie Kopalnia. Autor w poszukiwaniu s ocj o p s y ch ol og i c z n y ch

\footnotetext{
17 Tamże, s. 25.

18 Tamże, s. 27.

19 Tamże, s. 76.

20 Tamże, s. 75.

21 Tamże, s. 78.

22 Tamże, s. 67.
} 
czynników antagonizmu wnikliwie rozpatrywał funkcjonowanie stereotypów grupowych (między innymi przy tej okazji poruszona została obronna funkcja stereotypu), znaczenie mitu wroga, rolę myślenia magicznego, konserwatyzmu obyczajowego, relacje między polskimi i niemieckimi elitami władzy. $\mathrm{Z}$ pracy Chałasińskiego wyłania się obraz osady targanej antagonizmem polsko-niemieckim, obraz silnie podzielonej zbiorowości Murcek. Antagonizm jego zdaniem - rzutował na wszystkie sfery życia, opierał się na nim system społeczny osady. Podziały przebiegały przez śląskie rodziny, zbiorowości sąsiadów i górników. Współdziałanie możliwe było tylko w sferach narzuconych z zewnątrz. Powstał „konkretny i plastyczny obraz środowiska społecznego, w którym procesy antagonizmu przebiegają" 23 .

\section{TRZY RECENZJE}

Wysiłek Chałasińskiego został dostrzeżony po opublikowaniu wyników badań. Już w 1935 r. Jan Szczepański omawiając socjologiczne problemy Śląska w „Zaraniu Śląskim” odwoływał się do monografii Chałasińskiego - doskonałego „studjum antagonizmów społecznych na Śląsku” ${ }^{24}$. Przede wszystkim jednak w latach 1935-1938 pojawily się trzy opracowania krytyczne monografii Murcek. Autorami ich byli trzej badacze, których nazwiska zapisały się trwale w dziejach socjologii polskiej: Tadeusz Szczurkiewicz, Paweł Rybicki i Stanisław Rychliński ${ }^{25}$. Swe recenzje zamieścili w pismach o różnym charakterze („Ruch Prawniczy Ekonomiczny i Socjologiczny” - Tadeusz Szczurkiewicz, „Ekonomista” - Stanisław Rychliński, „Roczniki Towarzystwa Przyjaciół Nauk na Śląsku” - Paweł Rybicki), dając spojrzenie na pracę Chałasińskiego zarówno z perspektywy socjologicznej, jak i ekonomiczno-społecznej oraz regionalnej.

We wszystkich tekstach bardzo wysoko oceniono Antagonizm polsko-niemiecki. Recenzenci podkreślają jednoznacznie intuicję socjologiczną Chałasińskiego (,jedna $z$ najlepszych monografii socjologicznych, jakie ukazały się w ostatnich latach” - Szczurkiewicz ${ }^{26}$; „pierwsza bodaj w literaturze polskiej ściśle socjologiczna monografia miejscowości" - Rychliński ${ }^{27}$ ), jego zmysł obserwacji. Nie oznacza to jednak, że nie dostrzegają jednocześnie pewnych

23 Tamże, s. 137.

24 J. Szczepański, Socjologiczne problemy Śląska, „Zaranie Śląskie” 1935, z. 2.

25 P. Rybicki, Recenzja pracy J. Chatasińskiego: Antagonizm polsko-niemiecki w osadzie fabrycznej „Kopalnia” na Górnym Ślasku, „Roczniki Towarzystwa Przyjaciół Nauk na Śląsku”, t. 4, Katowice 1938, s. 370-372; S. Rychliński, Recenzja pracy J. Chałasińskiego: Antagonizm polsko-niemiecki w osadzie fabrycznej „Kopalnia” na Górnym Śląsku, „Ekonomista” 1935, t. 2, s. 11-112; T. Szczurkiewicz, Recenzja pracy J. Chatasińskiego: Antagonizm polsko-niemiecki w osadzie fabrycznej „Kopalnia” na Górnym Ślasku, „Ruch Prawniczy Ekonomiczny i Socjologiczny” 1937, nr 3.

26 T. Szczurkiewicz, Recenzja, cyt. wyd., s. 579.

27 S. Rychliński, Recenzja, cyt. wyd., s. 111 (Rychliński podkreśla, że praca Chałasińskiego znacząco odbiega od „bujakowskich monografij społeczno-gospodarczych”). 
uchybień, które widzą w braku wyraźnie określonych odniesień teoretycznych pracy, $\mathrm{w}$ tym przede wszystkim $\mathrm{w}$ nie do końca przemyślanej relacji między racjonalnymi a irracjonalnymi uwarunkowaniami procesów społecznych.

Zarzuty te pojawiają się w najobszerniejszej i najbardziej wnikliwej recenzji Szczurkiewicza. Dla poznańskiego socjologa Chałasiński jest „uczonym obdarzonym w niezwykłym stopniu wrodzonym zmysłem socjologicznym", gdyby jednak jeszcze ten sam Chałasiński „zechciał rozbudzić w sobie pasję do zagadnień czysto teoretycznych, dorównującą jego pasji do zanurzenia się w rzeczywistości społecznej, stałby się niewątpliwie jednym z największych socjologów, rewolucjonizujących w sensie najbardziej dodatnim socjologię" 28. Dla Szczurkiewicza Antagonizm polsko-niemiecki jest jedynie rozprawą z zakresu socjologii stosowanej ${ }^{29}$. Kluczowe dla niej pojęcia (na przykład stereotyp ${ }^{30}$, przywództwo) są mętne i nieprecyzyjne. Tylko „niezwykły zmysł” Chałasińskiego ratuje pracę przed „ześlizgiwaniem się umysłowym" 31 . Takie niedoprecyzowanie i niedookreślenie pojęć jest poważnym uchybieniem pracy. Co wydać się może ciekawe, odmienną opinię w tej kwestii wyraził Rychliński, dla którego „brak nużącej i zbytecznej terminologii" był zaletą pracy ${ }^{32}$.

Ta „ateoretyczność” pracy musiała mocno poruszyć Szczurkiewicza, gdyż kończąc recenzję ironizował w niespotykanym współcześnie stylu: „Ze względu na przyszłość rozwoju socjologii teoretycznej w Polsce, należy wyrazić życzenie, ażeby autor, jak najprędzej zaspokoiwszy swoją pasję zanurzenia się w rzeczywistości społecznej, rozbudził w sobie równie intensywne zainteresowanie dla zagadnień czysto teoretycznych, wykorzystując w pełni swoje wszechstronne uzdolnienia socjologiczne. Można żywić uzasadnioną nadzieję, że przy amerykańskim tempie pracowitości i ruchliwości Chałasińskiego, jego żywiołowa potrzeba kontaktu z coraz to inną rzeczywistością społeczną zostanie już wkrótce w pełni zaspokojona, a wówczas cała jego energia intelektualna zwróci się ku zagadnieniom analizy teoretycznej tym bardziej owocnej, że opartej na bezpośredniej, bogatej i wielostronnej znajomości życia społecznego" 33 .

Równie dyskusyjna wydaje się też Szczurkiewiczowi tendencja Chałasińskiego do irracjonalizowania dynamiki procesów społecznych. Krytycznie patrzy na zbyt silne akcentowanie „deprywacyj” oraz magicznego myślenia przy analizie stereotypów grupowych, stojąc na stanowisku, że przy ówczesnym

28 T. Szczurkiewicz, Recenzja, cyt. wyd., s. 573.

29 Tamże.

30 Część poświęcona stereotypom jest dla Szczurkiewicza zarazem najsłabszym i najbardziej ciekawym fragmentem pracy. „Najsłabsza ponieważ stosuje w niej najbardziej mętny termin «stereotyp" wprowadzony przez świetnego amerykańskiego publicystę, ale jednego z najgorszych teoretyków W. Lippmanna [...], najbardziej ciekawa i najlepsza, ponieważ demonstruje niezwykły trud i fenomenalną zręczność autora w unikaniu i wyswobadzaniu z sieci demonicznej wprost wieloznaczności"; tamże, s. 575.

31 Tamże, s. 574.

32 S. Rychliński, Recenzja, cyt. wyd., s. 112.

33 T. Szczurkiewicz, Recenzja, cyt. wyd., s. 580. 
stanie socjologii nie można zasadnie orzekać, „co i w jakim stopniu w procesach społecznych jest uzasadnione obiektywnie, a co należy położyć na karb irracjonalnej «mito-twórczości» ${ }^{34}$. Zarzuca Chałasińskiemu, że takie „irracjonalizowanie "racjonalnego" ma u podstaw zapominanie, zapoznawanie lub niedokładną znajomość konkretnej konstelacji warunków psycho-społecznych i kulturowych, w których powstawały pewne fakty społeczne, pewne procesy, nabierające $\mathrm{w}$ tych perspektywach charakteru «irracjonalności»" 35 .

Tendencja Chałasińskiego do irracjonalizowania procesów społecznych nie jest jednak tak oczywista. Niedookreślenie podstawowych pojęć, brak jednoznacznego określenia ram teoretycznych pracy pozwala na dojście do całkowicie przeciwnych konkluzji. Paweł Rybicki bowiem, odczytując pracę Chałasińskiego z odmiennej (niż Szczurkiewicz) perspektywy teoretycznej, chwali autora za nieracjonalizowanie procesów społecznych i wydobywanie ich irracjonalnych elementów. Zdecydowanie gani jednak za przewijającą się przez całość rozważań postawę racjonalistyczną, „która objawia się w pewnym zasadniczym deprecjonowaniu myślowych procesów irracjonalnych i opartych na nich działań, i w przeświadczeniu o wyższości bezwzględnej myślenia racjonalistycznego" ${ }^{36}$. Przykładem może być analiza mitu wroga, w której nie podjęto starań „wydobycia głębszych pokładów irracjonalnych postawy ludzkiej, na których wspiera się proces antagonizmu" 37 . Prowadzi to Rybickiego do konkluzji, że „praca Chałasińskiego kapitalna w niektórych chwytach, bardzo cenna w poszczególnych rezultatach, nie daje pełnego ujęcia zagadnienia antagonizmu społecznego. Uchyla się ono przed ujęciem badawczym pojętym na sposób analizy przyrodniczej" 38 .

Swych uwag krytycznych Szczurkiewicz nie ograniczył do kwestii irracjonalizowania dynamiki procesów społecznych. Zarzucił też Chałasińskiemu, że $\mathrm{w}$ swej analizie wykorzystał materiały zebrane w osadzie i prawie całkowicie pominął historyczne opracowania naukowe stosunków polsko-niemieckich. Odwołanie się do jednej popularnej broszurki to dla niego zbyt mało, tym bardziej że całkowicie pominięty został niemiecki punkt widzenia. To poważny zarzut, zważywszy z jednej strony na znaczenie, jakie przywiązywał do analizy historycznej autor Antagonizmu polsko-niemieckiego ${ }^{39}$, z drugiej zaś na specyfikę relacji polsko-niemieckich na śląskim pograniczu.

Nie przeszkadza to jednak Szczurkiewiczowi pozytywnie ocenić pracy Chałasińskiego. Według niego monografia „napisana jest żywo, z doskonałym poczuciem rzeczywistości, gęsto dokumentowana bystrymi obserwacjami

34 Tamże, s. 578.

35 Tamże.

36 P. Rybicki, Recenzja, cyt. wyd., s. 371.

37 Tamże.

38 Tamże, s. 372.

39 Por. C. Gryko, Józef Chałasiński. Socjologiczna teoria kultury, Wydawnictwo Lubelskie, Lublin 1989, s. 155-174. 
i znakomicie dobranymi wypowiedziami [...] członków osady [...] jest niezmiernie interesującym i wartościowym przyczynkiem, pozwalającym czytelnikowi widzieć, rozumieć i uczuciowo przeniknąć plastycznie zarysowany obraz antagonizmu polsko-niemieckiego w konkretnym, żywym zbiorowisku ludzkim” 40 . Pomimo tych zastrzeżeń „najsłabsze stronice tej monografii zawierają więcej socjologii, niż tasiemcowe rozprawy i grube tomy «socjologicznych" publikacyj" ${ }^{41}$. Dlatego ma znaczenie dla teoretyków i praktyków interesujących się problemami stosunków polsko-niemieckich.

Na praktyczną doniosłość dzieła Chałasińskiego zwrócił też uwagę kolejny recenzent - Stanisław Rychliński ${ }^{42}$. W swojej recenzji opublikowanej w szacownym już wówczas „Ekonomiście” pisał: „Dla ekonomisty i polityka społecznego monografja tego typu jest bardzo interesująca, daje bowiem pełne oblicze odbicia walk gospodarczych w płaszczyźnie życia świadomego ludzi w nie wplecionych. A co może ważniejsze - skutków przeżyć zbiorowych na ukształtowanie się ram społecznych, w których odbywają się procesy gospodarcze" 43 . Najważniejszą zaletą Antagonizmu polsko-niemieckiego w osadzie fabrycznej było bowiem dla Rychlińskiego dostrzeżenie znaczenia postaw społecznych dla zrozumienia konfliktów gospodarczych. Zauważał, że „W analizie postaw społecznych występuje cała złożoność procesów duchowych, autonomiczność zjawiska socjologicznego od fenomenu natury zewnętrznej, materjalnej, który wywołał zakłócenie równowagi wewnętrznej jednostek, w skład różnych grup społecznych wchodzących" ${ }^{4}$. Jednak patrząc z perspektywy klasowej, zarzucał Chałasińskiemu, że nie „zawsze uwzględnia należycie podłoże gospodarcze, a raczej zamiast uznać zjawiska ekonomiczne za podłoże, ujmuje je jako jeden z czynników bardziej złożonej sytuacji" ${ }^{45}$. Zalecał też zastosowanie metody materializmu ekonomicznego jako „stanowczo płodniejszej”, wydobywającej bowiem „momenty podstawowe w sposób znacznie plastyczniejszy” 46 .

Według Rychlińskiego, w pracy zabrakło też należytego wydobycia na światło dzienne "szarego życia osady" (kontrastuje to z opinią pozostałych recenzentów, którzy w tym aspekcie widzieli mocną stronę pracy). Praca, jego zdaniem, przede wszystkim „obraca się w atmosferze małej i wielkiej polityki, zbyt nieliczne są analizy tarć natury powszedniej, z codzienności gospodarczej wynikających. Wreszcie i samą osadę widzi się dosyć słabo, jakby przez mgłę, znów spowodu tego, że szare życie, jego troski i konflikty nie są dostatecznie uwypuklone" ${ }^{47}$. To poważny zarzut zważywszy, że dla Rychlińskiego konflikt

\footnotetext{
40 T. Szczurkiewicz, Recenzja, cyt. wyd., s. 577.

41 Tamże, s. 579.

42 St. Rychliński, Recenzja, cyt. wyd.

43 Tamże, s. 111.

44 Tamże, s. 112.

45 Tamże.

46 Tamże.

47 Tamże.
} 
polsko-niemiecki na śląskim pograniczu (w odróżnieniu od reszty kraju) miał głębokie podłoże właśnie $\mathrm{w}$ życiu codziennym ${ }^{48}$.

Pomimo sformułowania tak zasadniczych uwag krytycznych Rychliński dostrzega znaczenie pracy zarówno dla socjologów („którzy rozmawiają między sobą niezrozumiałym dla laika językiem uczonych terminów"), jak i praktyków ${ }^{49}$.

$\mathrm{Na}$ regionalne znaczenie pracy zwrócił uwagę Paweł Rybicki w swej recenzji zamieszczonej w „Rocznikach Towarzystwa Przyjaciół Nauk na Śląsku” (najważniejszym obok „Zarania Śląskiego” periodyku w życiu intelektualnym polskiego Sląska przed 1939 r.) ${ }^{50}$. Według związanego wówczas ze Śląskiem recenzenta, dystans do celów politycznych, obiektywizm i dobre zrozumienie terenu zaowocowały ważną i oryginalną pozycją dla piśmiennictwa regionalnego. Rybicki chwali przejawiającą się w pracy umiejętność podejścia do konkretnej rzeczywistości społecznej. Dzięki temu „obraz życia osady śląskiej [...], dobywa cały szereg rysów charakterystycznych środowiska śląskiego [...]. W samym tym obrazie mieści się poważny materiał obserwacyjny i orientacyjny" 51 .

Mimo dobrze oddanych śląskich realiów praca nie jest dla Rybickiego studium specyficznego konfliktu polsko-niemieckiego, ale analizą antagonizmu społecznego. Nie chodzi w niej o opis konkretnego konfliktu, ale o uchwycenie ogólniejszych prawidłowości. Ówczesny dyrektor Śląskiej Biblioteki Publicznej im. Józefa Piłsudskiego pisał: „nie bowiem o specyficzny problem polsko-niemiecki, tak jak by ujął polityk lub historyk chodziło autorowi, lecz o przykład typowego procesu społecznego. I tu za pomocą obserwacji, materiału danego przez żywe środowisko, dochodzi do wyników, które sięgają poza walor opisu i mają znaczenie ogólne" ${ }^{52}$. Szczególnie cenne są, jego zdaniem, uwagi Chałasińskiego o związkach między antagonizmem społecznym a strukturą społeczną pogranicza; roli, jaką dla budzenia i podtrzymywania antagonizmu mają osoby chwiejne co do swojej przynależności grupowej; czy też „przedstawienie antagonizmu jako procesu wewnętrznego w psychice czlowieka pogranicza" 53 .

Monografia osady Kopalnia jest dla Rybickiego pozycją ciekawą, „kapitalną w niektórych chwytach". Recenzent nie ukrywa jednak uwag krytycznych. Te związane są (jak już wspomniano) z „przebijającą się przez całość ujęć i rozważań” postawą racjonalistyczną, która nie daje możliwości pełnego „ujęcia zagadnienia antagonizmu społecznego”. Pomimo to zauważa: „Chałasiński dzięki swoim zainteresowaniom i szczególnym dyspozycjom naukowym zespolił w pracy swojej istotne wartości teoretycznej wiedzy, refleksji i ujęcia z realistycznym, pełnym nieraz szczegółów, opisem procesów małego konkretnego

\footnotetext{
48 Tamże, s. 111.

49 Tamże, s. 112.

50 P. Rybicki, Recenzja, cyt. wyd.

51 Tamże, s. 371.

52 Tamże.

53 Tamże.
} 
środowiska społecznego" ${ }^{54}$. Świadom jest też tego, że spór o racjonalistyczne podejście Chałasińskiego to w rzeczywistości spór o jedno „z podstawowych zagadnień metodologii nauk humanistycznych" 55 .

Przytoczone opinie o Antagonizmie polsko-niemieckim $w$ osadzie fabrycznej wskazują, z jak dużą uwagą podeszli recenzenci do monografii Chałasińskiego. Jednoznacznie pozytywnie ocenili intuicję autora, zmysł obserwacji. Krytyczne uwagi dotyczyły przede wszystkim nieprecyzyjnego użycia podstawowych terminów i nie do końca wyraźnego osadzenia badań w szerszym kontekście teoretycznym. Na dalszym tle pojawiły się kwestie związane ze śląskimi realiami i politycznym wydźwiękiem pracy. Choć przypuszczać należy, że i tu materiał zebrany przez Chałasińskiego mógł wówczas budzić kontrowersje. Świadczy o tym zakończenie monografii, w którym autor odnosi się do uwag swych naukowych przyjaciół. Zarzucili mu, że praca może zostać „wyzyskana dla celów walki politycznej polsko-niemieckiej” ${ }^{56}$. Chałasiński odpowiada, że jego praca „nie miała celów politycznych, szukał w niej jedynie socjo-psychologicznych czynników antagonizmu i całkowicie tym pochłonięty, nie zastanawiał się nad tem, czy i w jaki sposób pewne fragmenty mego studium mogą być wyzyskane dla celów politycznej walki" ${ }^{57}$. Kiedy jednak przyjaciele zwrócili mu na to uwagę, nie zmienil jednak nic w gotowej już monografii. Co więcej, w zdecydowany sposób skomentował zarzuty zaangażowania politycznego pisząc, że „powinniśmy już dawno wyjść z okresu uzasadniania swoich praw do Śląska, i z okresu obawy przed kwestjonowaniem tych praw przez kogokolwiek. Polski Górny Śląsk jest nasz i na tem koniec. Musi ulec całkowitemu spolszczeniu" ${ }^{58}$. W podobny sposób obszedł się zresztą z zarzutem pomijania materiałów niemieckich: „w opisie tym, jak łatwo czytelnik zauważy - pisał - opierałem się bezporównania więcej na materjałach, które otrzymałem od strony polskiej niż niemieckiej. Na skutek tego ucierpiała nie bezstronność pracy, ile jej wszechstronność. Mianowicie powojenne przeobrażenia niemieckie w osadzie nie zostały przedstawione tak szczegółowo jak polskie" 59 .

\section{POWOJENNA RECEPCJA MONOGRAFII CHAŁASIŃSKIEGO}

Po 1945 r. do zarzutów już nie wracano. Praca Chałasińskiego funkcjonowała jako klasyczny przykład monografii problemowej. Wspominano jej nowatorski charakter związany z konsekwentnym zastosowaniem zasady współczynnika humanistycznego ${ }^{60}$ lub porównywano ją ze szkołą badań historyczno-

\footnotetext{
54 Tamże, s. 370.

55 Tamże, s. 372.

56 J. Chałasiński, Antagonizm polsko-niemiecki, cyt. wyd., s. 135.

57 Tamże, s. 135-136.

58 Tamże, s. 136.

59 Tamże.

60 C. Gryko, Józef Chałasiński, cyt. wyd.
} 
-terenowych Kazimierza Dobrowolskiego ${ }^{61}$. Doceniano jej znaczenie dla rozwoju monografii problemowych ${ }^{62}$. Zdaniem Joanny Kurczewskiej monografia Chałasińskiego należała do najwartościowszych w polskiej przedwojennej socjologii prac poświęconych narodowi ${ }^{63}$. Doceniano też rozpoczęcie tą pracą polskich studiów nad stereotypami ${ }^{64}$ i przywoływano ją, kiedy podejmowano problem funkcjonowania stereotypów etnicznych na Górnym Śląsku ${ }^{65}$. Sięgali do tej pracy historycy (podejmując, jak Maria Wanatowicz ${ }^{66}$, problem antagonizmu polsko-niemieckiego na Górnym Śląsku) i badacze śląskiego życia literackiego ${ }^{67}$. W tym ostatnim przypadku autor dokonał interesującego zabiegu, konfrontując monografię Chałasińskiego z powstałymi w tym samym czasie utworami literackimi. W ten sposób rozważał kwestie funkcjonowania antagonizmu polsko-niemieckiego, stereotypów etnicznych i mitu wroga ${ }^{68}$. Dostrzegł też interesujące w kontekście współczesnych tendencji regionalnych na Górnym Śląsku stwierdzenie Chałasińskiego, że: „Regjonalizm występuje na Śląsku w postaci bardzo wyraźnej: on to sprawia, że w antagonizmie niemiecko-polskim na Śląsku poczucie odrębności śląskiej stanowi czynnik poważny. Ślązakom nie chodzi tylko o to, ażeby należeli do Niemiec lub Polski: byli Polakami lub Niemcami, ale żeby mogli pozostać sobą i gospodarzami swojej dzielnicy - Ślązakami” [podkr. T.N.] ${ }^{69}$.

Wreszcie odniesienia do monografii Chałasińskiego regularnie pojawiają się $\mathrm{w}$ pracach socjologów zajmujących się problematyką śląską. Przywołuje się ją jako przykład pierwszego polskiego „ściśle socjologicznego studium zjawisk występujących w regionie górnośląskim"70. Na tym tle wyróżniają się uwagi Antoniny Kłoskowskiej i Marka S. Szczepańskiego. W pracy Kultury narodowe u korzeni Kłoskowska wskazała na paradoks polegający na nie-

$61 \mathrm{H}$. Palska, O potrzebie monografii terenowej $w$ badaniach dawnej $i$ dzisiejszej biedy $w$ Polsce, w: K. Korzeniewska, E. Tarkowska (red.), Lata ttuste, lata chude... Spojrzenia na biedę w spotecznościach lokalnych, Instytut Filozofii i Socjologii PAN, Warszawa 2002.

62 I. Przybyłowska, P. Zygmanowski, Badania monograficzne $w$ środowisku wiejskim - historia i teraźniejszość, w: P. Starosta (red.), Zbiorowości terytorialne i więzi społeczne, Wydawnictwo Uniwersytetu Łódzkiego, Łódź 1995.

63 J. Kurczewska, Naród w socjologii i ideologii polskiej, PWN, Warszawa, 1979, s. 12.

${ }^{64}$ C. Gryko, Józef Chałasiński, cyt. wyd., s. 230.

65 M. Wanatowicz, Ludność naptywowa na Górnym Ślasku w latach 1922-1939, Śląski Instytut Naukowy, Katowice 1982, s. 297; Z. Hierowski, Życie literackie na Ślasku w latach 1922-1939, Śląsk, Katowice 1969, s. 208.

66 M. Wanatowicz, Ludność naptywowa, cyt. wyd., s. 274.

67 Z. Hierowski, Życie literackie..., cyt. wyd., s. 207-208.

68 Tamże. s. 207.

69 J. Chałasiński, Antagonizm polsko-niemiecki, cyt. wyd., s. 104. Zdaniem Hierowskiego (Życie literackie..., cyt. wyd., s. 20), podobne postawy występowały w utworach pisarzy, którzy „podejmowali śląskie tematy, a ze śląskim środowiskiem literackim nie związali się trwale” (Zbigniew Zaniewicki, Pola Gojawiczyńska, Ferdynand Goetel).

70 W. Mrozek, Tradycja badań, cyt. wyd., s. 7. 
zgodności stosowanej przez Chałasińskiego kategorii pogranicza (terenu, na którym „ześrodkowują się ekspansywne dążenia narodowo-państwowe i cała grupa wymaga od pogranicza bardziej aktywnego i ekspansywnego poczucia narodowego niż od mieszkańców centralnej części" ${ }^{71}$ ) z wnioskami, do których doprowadziła go jego analiza. Szkoda jednak, że autorka nie rozwinęła swego spostrzeżenia, poprzestając na podkreśleniu, że ta niezgodność nie wynika $z$ błędnej analizy, ale $z$ historycznej zmienności sytuacji pogranicza („nie znaczy to jednak, aby po jednej lub drugiej stronie tkwił błąd") ${ }^{72}$.

Z kolei Marek S. Szczepański w swym wystąpieniu na X Zjeździe Socjologicznym wspomniał o nadmiernym przerysowaniu relacji polsko-niemieckich w osadzie Kopalnia ${ }^{73}$. Niestety i on nie rozwinął swej tezy, choć należy przypuszczać, że do postawienia jej uprawniła katowickiego badacza znajomość powstałej po 1945 r. socjologicznej i historycznej literatury problemu.

Wniosków Chałasińskiego nie potwierdził też socjologiczny remake (badania ponowne ${ }^{74}$ ) zrealizowany $\mathrm{w}$ drugiej połowie lat dziewięćdziesiątych ${ }^{75}$. Odniesienie uzyskanych wówczas wyników do rezultatów prac przeprowadzonych $\mathrm{w}$ tym samym miejscu, ale $\mathrm{w}$ innym czasie przez Chałasińskiego pozwoliło na krytyczne ustosunkowanie się do tezy o antagonizmie polsko-niemieckim jako najbardziej żywotnym problemie osady. Zarówno analiza materiałów archiwalnych, jak i zachowany w pamięci zbiorowej obraz życia osady nie pozwala na tak ostre formułowanie tej tezy. Antagonizm istniał, ale dotyczył przede wszystkim elit lokalnych, deklarujących czy to z powodów autotelicznych, czy instrumentalnych polską lub niemiecką przynależność narodową. Mieszkańcy nie byli wcale tak mocno podzieleni ze względu na przynależność narodową. Wręcz przeciwnie murckowianie jednoznacznie zdeklarowani po polskiej lub niemieckiej stronie dobrze wspominali wzajemne relacje. Obie grupy jednak zdecydowanie negatywnie wyrażały się o „kabociarzach” (osobach koniunk-

71 J. Chałasiński, Antagonizm polsko-niemiecki, cyt. wyd., s. 78.

72 A. Kłoskowska, Kultury narodowe u korzeni, Wydawnictwo Naukowe PWN, Warszawa 1996, s. 278 .

73 M. S. Szczepański, Regionalizm górnoślaski między plemiennościa i systemem globalnym, w: Ślask Polska - Europa. Zmieniające się społeczeństwo w perspektywie lokalnej i globalnej. Xięga X Ogólnopolskiego Zjazdu Socjologicznego, A. Sułek, M. S. Szczepański (red.), Wydawnictwo Uniwersytetu Śląskiego, Katowice 1998, s. 22.

$74 \mathrm{Z}$. T. Wierzbicki, Metodologiczne rozważania o ponownych monografiach wiejskich spoteczności lokalnych, „Etnografia Polska” 1976, t. 20, z. 2.

75 Badania prowadzono w ramach indywidualnego grantu przyznanego przez KBN nt. „Stosunki społeczne w osadzie fabrycznej „Kopalnia” na Górnym Śląsku. Sześćdziesiąt lat po badaniach Józefa Chałasińskiego" (KBN PB/180/NS/96, Katowice). W następnych latach badania kontynuowano w ramach badań własnych Zakładu Socjologii Polityki Uniwersytetu Śląskiego, a w roku 2001 finansowane były ze środków będących w rezerwie Rektora UŚ na badania własne. Zob. T. Nawrocki, Stosunki społeczne w osadzie „Kopalnia” na Górnym Ślasku: śladami Józefa Chałasińskiego, w: Ślask - Polska - Europa, cyt. wyd. 
turalnie zmieniających identyfikację narodowa) i konfliktach $z$ tą grupą. Analiza materiału nie pozwala też na przyjęcie tezy o wyparciu lub zapomnieniu (w rozumieniu Franka A. Ankersmita) z pamięci zbiorowej antagonizmu polsko-niemieckiego ${ }^{76}$.

\section{CZY MONOGRAFIA OSADY KOPALNIA MA TYLKO WARTOŚĆ HISTORYCZNĄ?}

Czy w takim razie krytyka głównej tezy pracy i inne przywoływane tu zarzuty oznaczają, że dla współczesnego socjologa ma ona tylko wartość historyczną? Czy przyjrzenie się jej po ponad siedemdziesięciu latach od momentu powstania nie może być już przydatne dla badaczy z początków XXI wieku? Co po tak długim okresie pozostało istotne?

Odpowiedzi na te pytania przynosi sama praca. Pomimo upływu tylu lat śląskie badania Chałasińskiego bronią się same jako przykład socjologicznej intuicji i zmysłu badawczego. Do dziś mogą pozostać przykładem monografii żywej miejscowości, znakomicie oddają realia życia w świecie górniczej osady. W Antagonizmie polsko-niemieckim $w$ osadzie fabrycznej „Kopalnia” odnajdujemy barwny i złożony świat społeczności Murcek. Za Chałasińskim możemy odtwarzać jego strukturę społeczną, podstawowe problemy miejscowości, postawy i dążenia mieszkańców. Wyczulenie na historyczny aspekt zjawisk pozwala na odczytywanie dynamiki zachodzących tam procesów społecznych. Współczesny badacz uzyskuje w ten sposób wyjątkową możliwość odniesienia się do materiału socjologicznego sprzed ponad siedemdziesięciu lat. Krytyczne podejście do niego daje mu szansę prześledzenia przeobrażeń górniczej społeczności. Nie jest narażony na częste $\mathrm{w}$ przypadku badań monograficznych niebezpieczeństwo ograniczania się do porównania badanej społeczności z typem idealnym i ma możliwość pokazania zmian w niej zachodzących ${ }^{77}$.

$\mathrm{Z}$ pewnością udało się też autorowi zainspirowanie polskiej socjologii do badań monograficznych. Antagonizm polsko-niemiecki jest bowiem jedną z prac otwierających nowy rozdział $\mathrm{w}$ polskich badaniach monograficznych. Chałasiński, podobnie jak Krystyna Duda-Dziewierz (monografia Babic ${ }^{78}$ ), Kazimierz Dobrowolski (monografia wsi Niedźwiada ${ }^{79}$ ) i Jan Turowski (monografia Nasutowa ${ }^{80}$ ) wykracza poza schematyzm bujakowskiego modelu

76 F. R. Ankersmit, Wzniosłe odtaczenie się od przeszłości albo jak być/stać się tym, kim się już nie jest, tłum. J. Benedyktowicz, „Konteksty. Polska Sztuka Ludowa” 2003, nr 3-4.

$77 \mathrm{Na}$ takie uproszczone analizy społeczności lokalnych zwrócił uwagę Paweł Starosta w pracy Koncepcje zmiany wiejskiej społeczności lokalnej w tradycji socjologii polskiej, w: B. Jałowiecki, K. Z. Sowa, P. Dudkiewicz (red.), Społeczności lokalne. Teraźniejszość i przyszłość, Uniwersytet Warszawski, Warszawa 1989.

78 K. Duda-Dziewierz, Wieś małopolska, cyt. wyd.

79 K. Dobrowolski, Dzieje wsi Niedźwiada, cyt. wyd.

$80 \mathrm{~J}$. Turowski, Zmiany społeczne wsi a miasto. Na podstawie monografii wsi Nasutów $w$ okresie lat 1800-1946, TN KUL, Lublin 1948. 
monografii i podporządkowuje opis życia badanej miejscowości nadrzędnej problematyce ${ }^{81}$. Trudno dziś prowadzić badania monograficzne nie sięgając do dokonań Chałasińskiego.

Próbę czasu przetrwała też skłonność do dostrzegania irracjonalnych aspektów procesów społecznych. Tendencja ta, ganiona przez Szczurkiewicza, a doceniona przez Rybickiego, stanowi dziś o znaczeniu śląskiej monografii. Oczywiście rozwój refleksji w tym zakresie pozwalałby współcześnie na bardziej pogłębioną analizę, jednak należy docenić znaczenie, jakie przywiązywał Chałasiński do magicznego myślenia czy funkcjonowania mitu wroga. Wyjaśniając konflikty społeczne, nie należy zapominać o tym, co irracjonalne - to ciągle cenna wskazówka.

Mimo formułowanych wcześniej zastrzeżeń praca Chałasińskiego jest też nadal cennym źródłem informacji dla badaczy problematyki śląskiej. Krytycznie nastawiony socjolog odnajdzie $\mathrm{w}$ niej wiele interesujących spostrzeżeń, dotyczących na przykład relacji polsko-niemieckich na Górnym Śląsku, charakteru postaw narodowych na pograniczu społeczno-kulturowym, funkcjonowania stereotypów grupowych (zwłaszcza obronnej funkcja stereotypu), czy też przekona się o konieczności uwzględniania perspektywy historycznej w tłumaczeniu współczesnych problemów społecznych Górnego Śląska. Ważne jednak, by śląski wymiar monografii odczytywać w kontekście ustaleń późniejszych historyków i socjologów badających problematykę tego regionu. $\mathrm{Na}$ przykład korzystając z przywoływanej tu kategorii pogranicza, warto uwzględnić to, co do rozumienia tego pojęcia wnieśli tacy autorzy jak Paweł Rybicki, Józef Chlebowczyk czy Antonina Kłoskowska ${ }^{82}$.

Antagonizm polsko-niemiecki jest wreszcie atrakcyjny dla osób po prostu pasjonujących się Górnym Śląskiem. Nadal może być ciekawy dla wszystkich tych, którzy starają się lepiej poznać specyfikę tego regionu. Odnajdą w nim zapis świata, który choć odchodzi w przeszłość, to nadal wywiera wpływ na współczesny Śląsk (na przykład specyfika identyfikacji narodowościowej, rola tradycji itp.).

Dlatego może po ponad siedemdziesięciu latach warto sięgnąć do tej monografii, przywrócić polskiej socjologii i badaniom śląskoznawczym ważną pracę wybitnego polskiego socjologa. Krytyczne wydanie tego nigdy nie wznawianego dzieła, z pewnością poprawiłoby jego recepcję w środowisku badaczy, a Antagonizm polsko-niemiecki w osadzie fabrycznej "Kopalnia” na Górnym Ślasku zająłby należne mu miejsce $\mathrm{w}$ dorobku polskiej socjologii, a także w polskich badaniach społecznej problematyki Górnego Śląska.

81 Por. J. Turowski, Monograficzne badania wsi, „Wieś i Rolnictwo” 1977, nr 2.

82 P. Rybicki, O badaniu socjograficznym Ślaska, Katowice 1938; J. Chlebowczyk, O prawie do bytu matych i młodych narodów, PWN, Warszawa-Kraków 1983; A. Kłoskowska, Kultury narodowe, cyt. wyd. 


\section{A REFLECTION ON THE RECEPTION OF JÓZEF CHAŁASIŃSKI'S MONOGRAPH}

\section{Summary}

The author recalls a now-classic monograph of a Silesian housing estate, written by Professor Józef Chałasiński, an outstanding Polish sociologist, entitled Polish-German Antagonism in the "Kopalnia" Factory Housing Estate in Upper Silesia. He discusses the basic assumptions of this monograph and the main theses of its three pre-war reviews (by Paweł Rybicki, Stanisław Rychliński, and Tadeusz Szczurkiewicz). He then presents the post-war reception of Professor Chałasiński's research, and closes by reflecting on the topicality of this monograph.

\section{Key words/słowa kluczowe}

history of Polish sociology / historia polskiej socjologii; Józef Chałasiński; Silesia / Śląsk 